\title{
Chapter 2 \\ Damned If You Do, Damned If You Don't: The Challenges of Including and Comparing the Children of Immigrants in European Survey Data
}

\author{
Laurence Lessard-Phillips, Silvia Galandini, Helga de Valk, and Rosita Fibbi
}

\subsection{Introduction}

The comparative project as well as the level of analysis chosen thus to a great extent structure the conclusions. There is no right or wrong way to construct a comparison, but it is necessary to be aware of the ways in which certain choices at the inception reflect options concerning the similarities or singularities of the immigrant experience. Green (1994: 14)

Since the 1970s, there has been an overall increase in cross-national studies in Europe covering different domains of life. The overarching idea behind this trend is that such studies would allow comparisons across countries and would lead to a better understanding of the importance of the national context in explaining crossnational differences (Breen and Jonsson 2005; Heath and Cheung 2007). In addition, it has been suggested that this would also be a good point of reference for policymakers to learn about the effectiveness of various policy measures (Thomson and

\footnotetext{
L. Lessard-Phillips ( $\square)$

Institute for Research into Superdiversity (IRiS), OrgUniversity of Birmingham,

Birmingham, UK

e-mail: 1.lessard-phillips@bham.ac.uk

S. Galandini

Cathie Marsh Institute for Social Research and Sociology, University of Manchester,

Manchester, UK

e-mail: silvia.galandini@manchester.ac.uk

H. de Valk

Netherlands Interdisciplinary Demographic Institute/KNAW University of Groningen,

Groningen, The Netherlands

e-mail: valk@nidi.nl

R. Fibbi

Swiss Forum for Migration and Population Studies, University of Neuchâtel,

Neuchâtel, Switzerland

e-mail: rosita.fibbi@unine.ch
}

C. Bolzman et al. (eds.), Situating Children of Migrants across Borders and

Origins, Life Course Research and Social Policies 7,

DOI 10.1007/978-94-024-1141-6_2 
Crul 2007; Dronkers and De Heus 2013). International organizations such as the OECD or the ILO have been supporting this cross-national research methodology and the EU has fostered this further in their research programs in the past decade.

The fields of migration and ethnic studies have been no strangers to this trend, with national borders of studies being increasingly crossed (Bovenkerk et al. 1991) and migration no longer being perceived as a simple national issue but as a more global issue, linked, for example, to the development and maintenance of diasporas or attempts to coordinate migration and integration across the EU (Guiraudon 2003; Collett 2013). Migration, which is in itself nothing new in Europe but has changed with regard to the origins of migrants (Lucassen and Lucassen 2013), is one of the key drivers in population change in almost all European societies. The proportion of children of immigrants either born in European societies or migrating at a young age is of growing importance for populations, societies, and economies across Europe. It is therefore getting more relevant, and easier, to have a better understanding of the lives of these 'new', diverse members of society from a sociological perspective to understand the opportunities and barriers they face.

As noted above, this quest for more knowledge on diverse populations has heralded the need for more comparative studies with a focus on the children of immigrants in Europe. This has been done either by focusing data collection efforts exclusively on the children of immigrants ${ }^{1}$ or including variables in more general surveys permitting to identify various immigrant generations, ${ }^{2,3}$ allowing for quantitative analyses of their life outcomes, be them linked to health, education, or

\footnotetext{
${ }^{1}$ The surveys that we outline in this chapter are recent surveys dealing directly with the children of immigrants. These include the following: Children of Immigrants Longitudinal Survey in Four European Countries (CILS4EU); Ethnic Differences in Education and Diverging Prospects for Urban Youth in an Enlarged Europe (EDUMIGROM); Effectiveness of National Integration Strategies forwards Second Generation Migrant Youth in Comparative European Perspective (EFFNATIS); Generating Interethnic Tolerance and Neighborhood Integration in European Urban Spaces (GEITONIES); Multicultural Democracy and Immigrants Social Capital in Europe: Participation, Organizational Networks, and Public Policies at the Local Level (LOCAL MULTIDEM); Six Country Immigrant Integration Comparative Survey (SCIICS); and The Integration of the European Second Generation (TIES). A more detailed overview of the available data can be found in Table 2.3.

${ }^{2}$ The non-specific surveys that we have identified as potentially relevant for the study of children of immigrants are the EU Labour Force Survey - EU-LFS, particularly the 2008 and 2014 ad-hoc modules on the labour market situation of migrants and their immediate descendants (European Commission 2011; EUROSTAT website); the European Union Statistics on Income and Living Conditions - EU-SILC (Kampakoglou et al. 2012; EUROSTAT 2013); European Value Study (EVS 2013); Eurobarometer (Gesis 2014; TNS Opinion and Social 2011)); European Social Survey (ESS 2013); Generations and Gender Programme (GGP 2013); Programme for International Student Assessment - PISA (Adams and Wu 2002; OECD 2005, 2006, 2009, 2012a; Schleicher 2006); Progress in International Reading Literacy Study -PIRLS (PIRLS 2013); and Trends in International Mathematics and Science Study - TIMSS (Foy et al. 2011). Given that their target populations are not children of immigrants per se, these surveys will not be examined in this chapter.

${ }^{3} \mathrm{We}$ are aware that there are national datasets that offer opportunities to study the children of immigrants in a comparative perspective, but these sources are not the focus of our chapter. See the edited volume by Heath and Brinbaum (2014) for an example on how national data can be used in a comparative manner.
} 
employment outcomes, to only name a few. One of the main underlying aims of such research, which is gaining in importance and is the recipient of sustained academic and policy-interest, is to examine the outcomes of the children of immigrants usually using a given benchmark for comparison, and understand the source of the potential differences in outcomes using available data.

Undertaking such comparative research is not, however, without its problems. There are important issues that arise from comparatively studying the children of immigrants, some of which echo those recently raised by Bloemraad (2013) in the broader field of migration research. Among the main issues that arise from such comparative endeavors are the level at which we make those comparisons (e.g., local, provincial, national, cross-national, etc.); who we are comparing the children of immigrants to (i.e. the 'benchmark' for measuring integration outcomes); and what kind of selectivity/selection bias and generalization issues arise from analyzing data on the children of immigrants. In our opinion, these issues, which are rooted in both theoretical and practical considerations, have important consequences on the types of analyses that can be performed as well as the conclusions that can be drawn from those comparisons. In this chapter we will examine and discuss these issues drawing from examples of available European data.

This chapter starts by giving an account of the ways in which the children of immigrants have been identified in current sociological survey data. Following that we discuss the levels of analysis used in the existing data, and then the different types of comparisons available to researchers. We finish by a discussion of the various biases involved in analyzing the children of immigrants using quantitative data, from selectivity issues to cohort and age effects.

\subsection{Defining the Children of Immigrants in Survey Data: Who Are We Talking About?}

Children of immigrants can be immigrant themselves (having migrated with their parents before becoming adults) or have parents who migrated before they were born. Existing literature on the children of immigrants has tended to differentiate between 'types' of individuals with immigrant parentage using an 'immigrant generations' typology, where later generations imply more distance with immigrant parentage. In this typology there is an underlying assumption that varying types of immigrant parentage might imply varying impact of such parentage (Heath et al. 2008; Alba and Holdaway 2013). The typical classifications that are of interest to us and the data sources examined are the following (see McAndrew and Voas 2014; Parameshwaran 2014; Rumbaut 2002, 2004; Rumbaut et al. 2006; and Waters 2014 for more details):

- First generation: individuals who migrated ${ }^{4}$ to the host country as adults $(18+)$;

\footnotetext{
${ }^{4}$ Note that we focus on individuals who had migrated to the host/survey country at the time of the survey; this might include individuals with different migration trajectories, for example children of immigrants who have migrated themselves, who would be from the second generation in one
} 
- 1.25 generation: individuals who migrated to the host country as teenagers (13-17);

- 1.5 generation: individuals who migrated to the host country as older children (6-12);

- 1.75 generation: individuals who migrated as young children (0-5);

- Second generation: individuals who were born in the host country but have two migrant parents;

- 2.5 generation: individuals who were born in the host country but have one migrant parent;

- Third generation: individuals born in the host country of host-country born parents, with one or more immigrant grandparents; and

- Fourth generation: individuals with parents and grandparents born in the host country.

These are the types of individuals that can potentially be identified in data allowing the study of children of immigrants, based on the assumption that immigrant parentage plays a long-lasting role in the integration process. The typology above presents quite a broad and granular classification of individuals with an immigrant parentage, which is not often used in quantitative research, often due to lack of large sample size and information allowing the identification of such respondents.

If we turn to official figures reporting the size of the first and second generation in Europe as published by Eurostat in the left pane of Table 2.1, (European Commission 2011) we can see that individuals with a migrant background are a non-negligible share of the population in most of these countries. Prognoses made by Eurostat also show that in the EU-27 the share of the population with an immigrant origin will increase in all age groups in the decades to come (Lanzieri 2011). This applies in particular to the young.

Again this is also clear from the second pane of Table 2.1 where the share of first and second generation 15-year olds are provided based on the PISA data by the (OECD 2012b). Whereas the shares of those of immigrant origin in the total population is sometimes still limited, the importance for those in school age is clearly higher already now. The surveys that we are examining in this chapter deal with this important, and growing, proportion of the population with an immigration background.

With regard to the national origins of these groups, official figures do not provide detailed comparative information by country of origin. At the same time both stock and flow statistics on migrant populations indicate that a substantial share of the total migration population has a European (EU27) origin (see, for example, de Valk et al. 2015; Lanzieri 2011). This is also clear from Table 2.2, based on OECD data (OECD 2012) showing the main regional origins of adults of migrant origin in which the majority come from Europe (but not necessarily from OECD nations), Asia (including Turkey), and Africa (including Morocco).

country but from the first generation in another. Whilst we accept that this might be the case for some individuals from the first generation, we do not focus on such individuals, as they are not assumed to form a great proportion of the target populations included in this chapter. Many surveys, including those examined in this chapter, include questions on multiple migration histories or mobility so grasp such histories. 
Table 2.1 Individuals of migrant origins in Europe by age group and current country of residence (Adult population: European Commission 2011; Student population:OECD 2012b)

\begin{tabular}{|c|c|c|c|c|c|}
\hline & \multicolumn{3}{|c|}{ Proportion of adult population (\%) } & \multicolumn{2}{|c|}{$\begin{array}{l}\text { Proportion of student } \\
\text { population }(\%)\end{array}$} \\
\hline & \multicolumn{3}{|c|}{$(25-54-2008)$} & \multicolumn{2}{|c|}{ (15 year olds -2009$)$} \\
\hline & $\begin{array}{l}\text { First } \\
\text { generation }\end{array}$ & $\begin{array}{l}\text { Second } \\
\text { generation }\end{array}$ & $\begin{array}{l}2.5 \\
\text { generation }\end{array}$ & $\begin{array}{l}\text { First } \\
\text { generation }\end{array}$ & $\begin{array}{l}\text { Second } \\
\text { generation }\end{array}$ \\
\hline Belgium & 14.7 & 4.0 & 4.1 & 6.9 & 7.8 \\
\hline Czech Republic & 3.0 & 0.9 & 3.3 & 0.8 & 1.4 \\
\hline Denmark & 8.6 & na & na & 2.8 & 5.9 \\
\hline Germany & 81.4 & 2.9 & 1.4 & 5.9 & 11.7 \\
\hline Greece & na & na & na & 6.1 & 2.9 \\
\hline Spain & 75.8 & 0.2 & 0.9 & 8.4 & 1.1 \\
\hline France & 5.8 & 1.0 & 7.7 & 3.2 & 10 \\
\hline Italy & 10.6 & 0.1 & 0.9 & 4.2 & 1.3 \\
\hline Hungary & 2.2 & 0.3 & 0.6 & 1.2 & 0.9 \\
\hline The Netherlands & 35.6 & 2.7 & 5.8 & 3.2 & 8.9 \\
\hline Austria & 18.4 & 1.9 & 5.0 & 4.8 & 10.5 \\
\hline Poland & 0.3 & 0.8 & 2.1 & na & na \\
\hline Portugal & 10.5 & 0.4 & 0.8 & 2.8 & 2.7 \\
\hline Romania & 0.2 & na & na & 0.2 & 0.1 \\
\hline Slovakia & 0.9 & 0.4 & 1.6 & 0.3 & 0.3 \\
\hline Sweden & 16.2 & 2.9 & 6.7 & 3.7 & 8.0 \\
\hline UK & 15.6 & 3.8 & 5.0 & 4.8 & 5.8 \\
\hline Switzerland & 31.1 & 5.7 & 9.6 & 8.4 & 15.1 \\
\hline
\end{tabular}

The 2009 report from the UNICEF Innocenti Research Centre, in which the position of children of immigrants in eight affluent countries was compared using official statistics, showed that main origins of immigrant children differ across European countries. In most of the studied countries the second generation clearly outnumbered the first generation among those below 18 years of age (see e.g. de Valk 2010). At the same time, the origins of the children in migrant families clearly reflected the migration histories of each of these countries, including colonial and labor migration in the past century as well as European mobility (Hernandez et al. 2009). A recent exploration of the origins of children of immigrants (second generation) in 10 Western countries (Lessard-Phillips et al. 2014) showed a similar pattern. The main origins of the second generation in Belgium are Turkey, Morocco, and Italy; India, Pakistan, and Bangladesh in England and Wales; Overseas department and territories (Dom/Tom) and French born abroad, Maghreb, and Portugal in France; Turkey, Former Soviet Union and Former Yugoslavia in Germany; Surinam/ Antilles, Morocco, and Turkey in the Netherlands; Finland, Turkey and Iran in Sweden; and Italy, Former Yugoslavia, and Spain/Portugal in Switzerland.

As mentioned in the introduction, quite a few recent European surveys either focus on children of immigrants or allow categorizing these individuals by more coherently including relevant information to identity them. The former allow for 
Table 2.2 Main region of origin (and proportion) of foreign-born individuals aged 15 and over by country of current residence (2000) (OECD 2012b)

\begin{tabular}{|c|c|c|c|}
\hline & First region (\%) & Second region $(\%)$ & $\begin{array}{l}\text { Proportion from } \\
\text { OECD }(\%)\end{array}$ \\
\hline Belgium & Europe (67.7) & Africa (22.8) & 66.1 \\
\hline Czech Republic & Europe (92.9) & Asia (4.7) & 77.3 \\
\hline Denmark & Europe (55.7) & Asia (30.2) & 50.1 \\
\hline Germany & Europe (68.6) & Unspecified (15.7) & 41.8 \\
\hline Greece & Europe (80.8) & Asia (8.4) & 28.2 \\
\hline Spain & $\begin{array}{l}\text { South/Central America/the } \\
\text { Caribbean (37.9) }\end{array}$ & Europe (37.3) & 32.2 \\
\hline France & Africa (49) & Europe (40.8) & 39.7 \\
\hline Italy & Europe (55.4) & Africa (20.2) & 39.1 \\
\hline Hungary & Europe (94.3) & North America (0.9) & 23.6 \\
\hline The Netherlands & Europe (37.3) & Asia (22.8) & 28.9 \\
\hline Austria & Europe (89.1) & Africa (2.4) & 50.0 \\
\hline Poland & Europe (95.3) & Unspecified (2.1) & 20.1 \\
\hline Portugal & Africa (56.7) & Europe (27.3) & 25.8 \\
\hline Romania & Europe (80.6) & Asia (11.3) & 15.8 \\
\hline Slovakia & Europe (97.5) & Asia (1.3) & 85.0 \\
\hline Sweden & Europe (62.1) & Asia (6.0) & 47.8 \\
\hline UK & Europe (34.5) & Asia (32.8) & 38.6 \\
\hline Switzerland & Europe (77.8) & Asia (6.4) & 62.6 \\
\hline
\end{tabular}

directly surveying target populations of interest, include a wealth of information specific to the populations under study but do not offer great flexibility with enabling data users to define their own target population. The latter, on the other hand, can be quite flexible for researchers, as the availability of country of birth information at the individual/parental/grandparental level, citizenship, ${ }^{5}$ or ethnicity information allows creating target populations according to their own (theoretical) criteria. At the same time analyses based on such data, especially over time, are hampered by the fact that different data collection waves include different kinds of information, making the consistent identification of immigrants and their descendants difficult. In this chapter, we focus on the surveys having children of immigrants as their main group of interest and how they define their target populations. These surveys can

\footnotetext{
${ }^{5}$ One major challenge to surveying the children of immigrants in general survey data comes from using 'country of birth' as a selection criterion, as such information is not always readily available in different national contexts. In Switzerland, for example, nationality has been the only selection criterion for many years; it has only recently been possible to identify children of immigrants according to country of birth (Fibbi et al. 2005). In France, on the other hand, issues of identification via ethnic or national origin are still very much problematic (Simon 2003). These selection criteria have important effects on selection, which will be discussed below. Moreover, given the complexity of migration histories, information about country of birth and citizenship may not be enough. Information about the type of migration and naturalization (including the date) might be important to further understand the position that children of immigrants hold in the receiving societies.
} 
offer researchers more comparable wealth of targeted information about the important aspects of the lives of the children of immigrants, which are not necessarily available in non-specific surveys. Whilst a challenging endeavor, designing such surveys is important for gathering specific information on populations of interest and can provide evidence for theory building. The surveys under consideration in this chapter, as well as the broad aspects that we are discussing, can be found in Table 2.3.

The choice of which individuals to include has an important impact on the data collection; the type of questions that can be answered; the refinement of the analyses that we can conduct; and the types of conclusions we can draw about these groups. The definition of the target populations varies widely across the surveys under study. Moreover, many of these surveys focus on the early stage of life, such as childhood or young adulthood. This is primarily because the children of immigrants are still relatively young (European Commission 2011) since larger waves of migration to Europe has been relatively recent (Lucassen and Lucassen 2013). Before going into detail about the potential impact of these choices, we will discuss them in some detail to clarify the issue.

The criteria for inclusion that we find in the European data range from being inclusive (i.e. including individuals with any immigrant background, including those born abroad) to exclusive (i.e. only including individuals born in the survey country with parents born abroad). The CILS4EU data, ${ }^{6}$ which samples school pupils, is a prime example of the inclusive approach, as individuals either born abroad or with at least one immigrant parent were included in the target group (Dollmann et al. 2014). It could also be argued that their criteria for inclusion is slightly more specific, as it includes the 1.5 generation (as well as the second and potentially the third), which are individuals born abroad but who migrated as children and/or young adults and therefore conducted some, if not all, their schooling career in a given host country. ${ }^{7}$ On the one hand, this study steers away from exclusively focusing on the children of immigrants per se, but allows for a broader inclusion of typically excluded groups, which can be used for a more refined level of comparison (see below). The EDUMIGROM project is also an example of a more inclusive survey, as it selected young people of various ethnic origins, the majority of whom were born in the survey country (Szalai etal.2010). The LOCALMULTIDEM project was similarly rather inclusive in its selection criteria, allowing respondents to be of the first, second, or even third generation (Morales and Giugni 2011). The GEITONIES project included individuals with at least one parent born abroad in their target group without specifying any other criteria for inclusion (Fonseca et al. 2013). At the other end of the range we have the more exclusive TIES survey target group that consists in young adults of Turkish, Moroccan, and ex-Yugoslav origin born in the survey countries, who have at least one foreign-born parent. Analysis of these data looking into the mixed immigrant parentage of the TIES respondents

\footnotetext{
${ }^{6}$ We would also like to acknowledge the Children of Migrants Longitudinal Survey (CILS) that was conducted in Spain (Madrid and Barcelona) in 2010 (Portes et al. 2010).

${ }^{7}$ Definitions of the 1.5 generation vary widely in the literature and do not always follow the categorization outlined earlier in the chapter.
} 


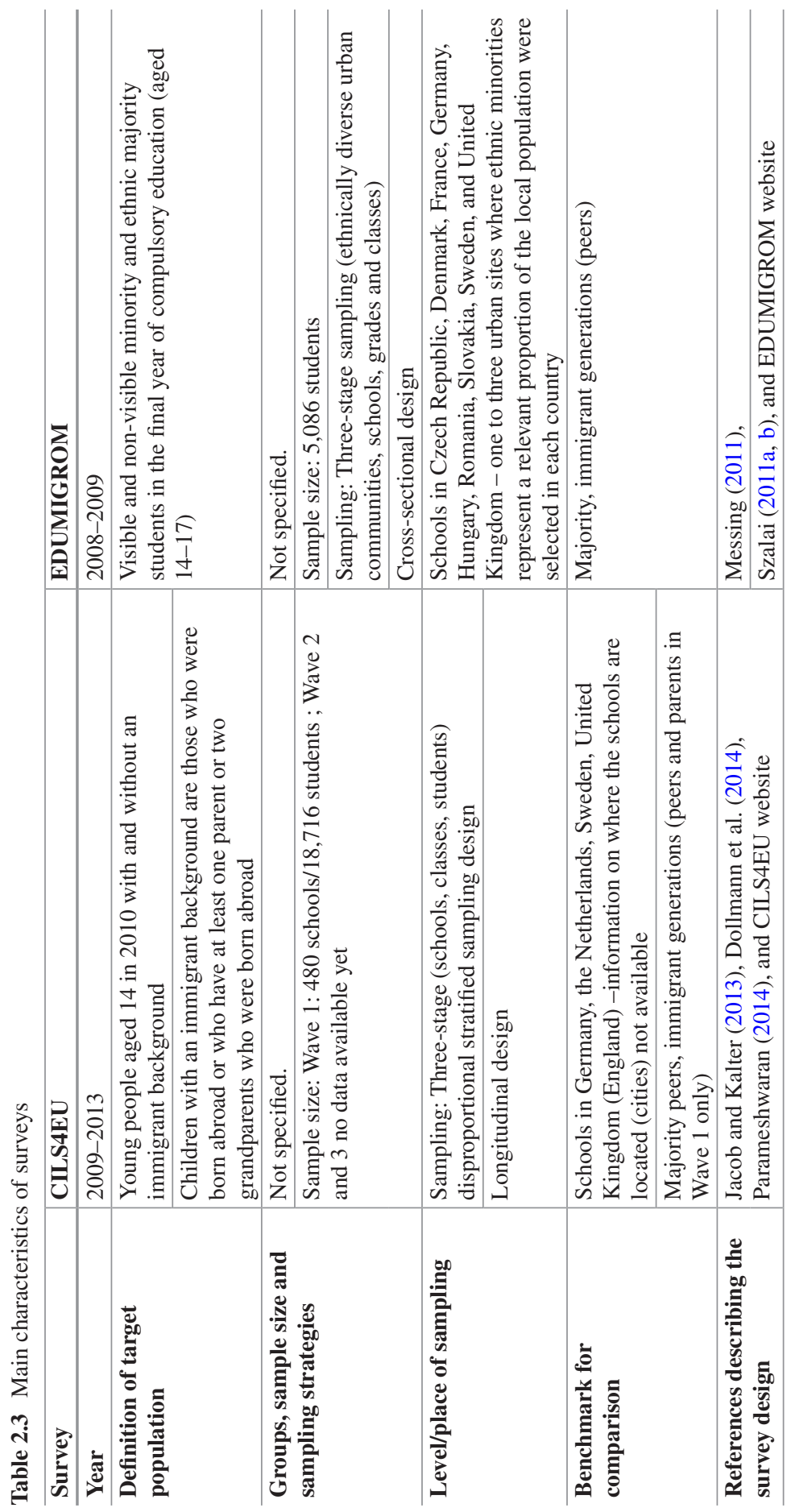




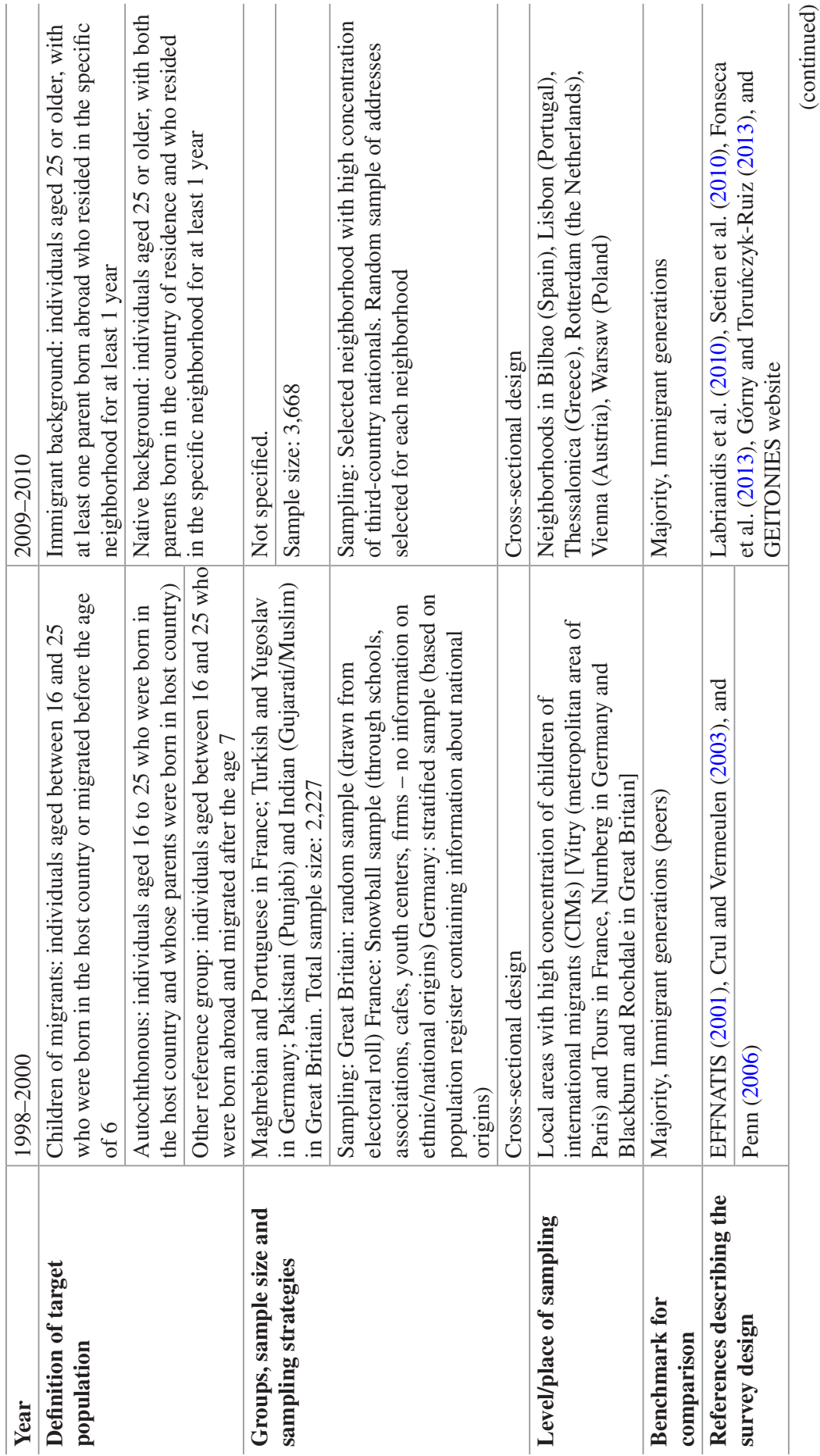




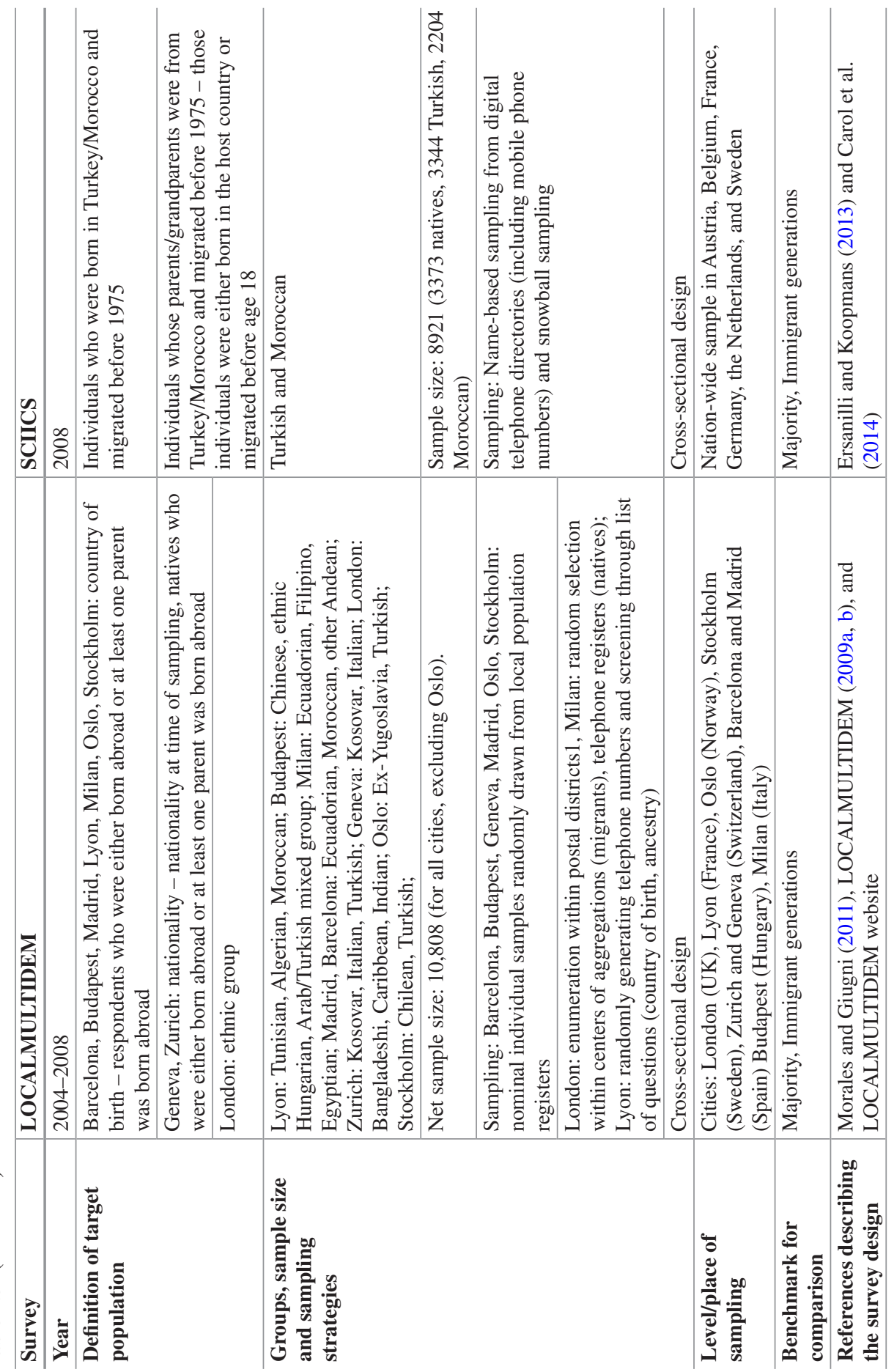




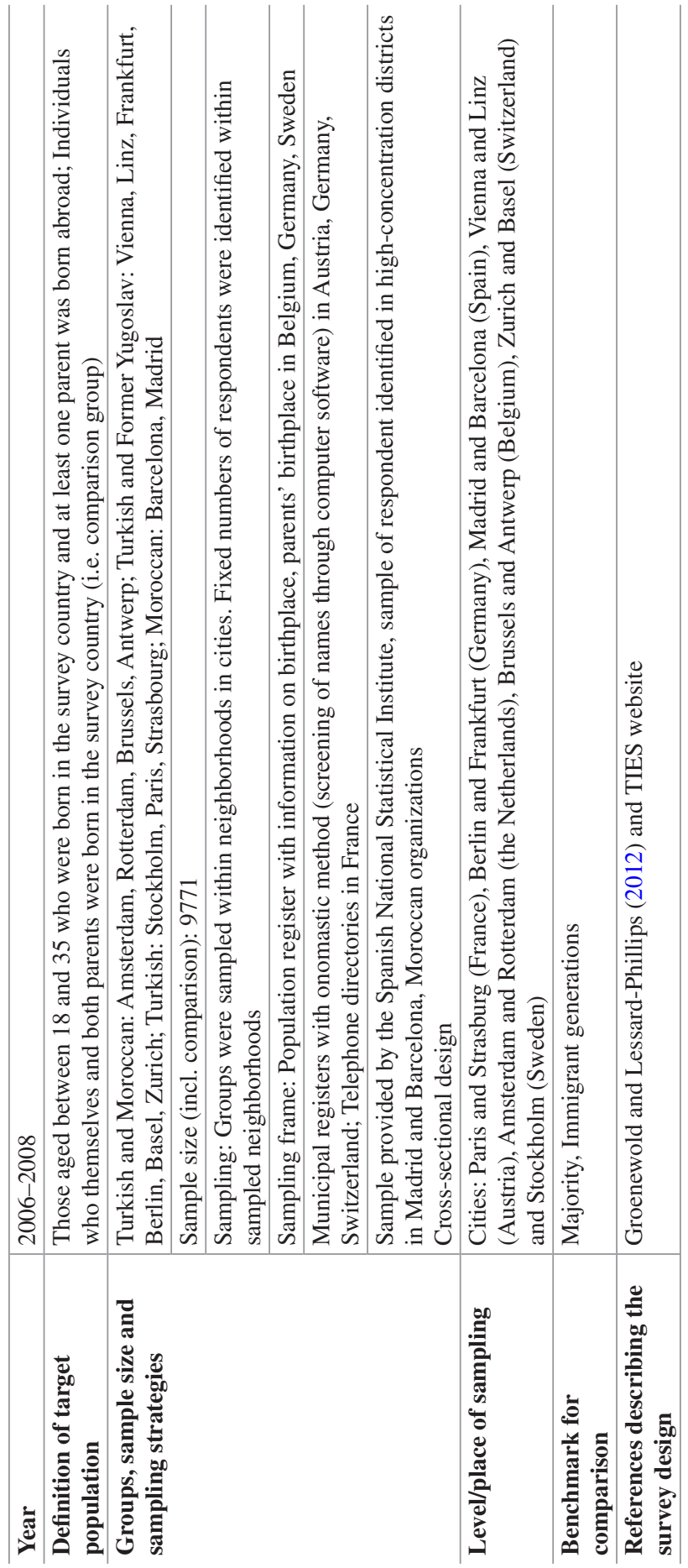


show that most of the second-generation respondents had 2 parents born abroad (Lessard-Phillips and Ross 2012).

In between the data using either the exclusive or inclusive criteria are the other surveys using a mixture of the two approaches. The EFFNATIS project covered individuals who migrated to the survey country before age 6 as a target group, which is approximately the start of compulsory schooling, but also included individuals who migrated later (EFFNATIS 2001). The SCIICS data included in its target group individuals of Turkish and Moroccan descent who either migrated as children $(<18)$ before 1975 or born in the survey country with parents and/or grandparents who migrated before 1975 (Ersanilli and Koopmans 2013). In principle this survey also includes the third generation into their target samples, even if the size of this group is still quite small in most European countries.

In some cases, the ethnic/national origin of the children of immigrants was part of the definition of the target population. This is the case for all surveys covered in this chapter aside from CILS4EU, EDUMIGROM, and GEITONIES. In terms of the national origins of the survey respondents (or their parents), we see a wide yet consistent coverage of the main immigrant groups mainly following the most prominent national origins found in official national data outlined earlier in the chapter.

\subsection{Levels of Analysis}

Another important component of comparative research on the children of immigrants concerns the geographical levels (local, national, etc.) at which comparisons are made and the types of groups that are used in such comparisons. Choosing the level of analysis has major conceptual implications and suits different research questions. This is an issue that has been ever present in recent migration research. In 1991, Bovenkerk et al. concluded that defining the correct level of comparison in European migration research is difficult, as research at the time either 'mirrored' European findings to that in one particular country or lacked a meaningful comparison point at all and took a too general approach. Given the short supply of general theories that can be or are applied, Bovenkerk and colleagues argued that comparisons in this sense run the risk in being solely descriptive and not really add to the explanation of phenomena. They concluded that the choice between generalization and specificity requires different levels of abstraction (Bovenkerk et al. 1991).

With an outlook toward more general migration research, Green (1994) outlined three different models of comparison that are often used when thinking about the choice between level and groups: the linear model, the convergent model, and the divergent model. Given that the linear model, which focuses on following immigrants from origin to destination, does not necessarily relate to the experiences of the children of immigrants, it will not be explored in this section. ${ }^{8}$ Convergent mod-

\footnotetext{
${ }^{8}$ It can nonetheless be the case that following the parents and their migration motives and patterns is important for understanding the outcomes of their children.
} 
els of comparison tend to study various immigrant groups in the same place, either an immigration country or a city. ${ }^{9}$ These models, which stress the specificities of each group included in the comparison, are most often found in national research. Whilst allowing an in-depth focus at the group level in a specific place, convergent models tend to wipe off the changing historical conditions of social and economic participation for each group in the host countries. Divergent models, on the other hand, study one immigrant group in various destination places, allowing for a focus on contextual factors shaping the opportunities and barriers for integration. In her methodological essay Green explained that "divergent studies [, which are rare,] locate the explanation of difference at the point of arrival and not at the point of departure" (1994: 15).

The examples cited in this chapter suggest that European data contains a mixture of convergent and divergent models. For the data comparing similar groups across places (such as SCIICS and TIES), the comparative strategy seems to be that of an extensive divergent model of comparison, moving beyond the observation on one specific group across countries and extending it to a certain number of specific groups. For the data comparing different groups across different places (such as CILS4EU and EFFNATIS), we can also talk about an extension of convergent models.

The trend towards divergent models of comparison appears to have become more common in European research in the last decade (Ersanilli and Koopmans 2009; Huschek et al. 2010; Fleischmann and Phalet 2012). Two different sets of factors may account for this trend: theoretical and political. On the one hand, the change toward divergent research designs, especially those focusing on the local level, was triggered by the sharp critique of methodological nationalism, "the assumption that the nation/state/society is the natural social and political form of the modern world" (Wimmer and Glick Schiller 2002: 302). The nation-state is obviously an important actor in setting out rules and regulations with regard to the entry and settlement of migrants. It should not be ignored when studying migrants and their descendants (Guiraudon and Lahav 2000; Teitelbaum 2001). However, critiques of this viewpoint questioned the "naturalization" of the geo-political frame of nation-states as encompassing societal phenomena in general. In the specific case of the study of migration, it was argued that the focus on nation-states might be counterproductive for understanding migration and integration experiences (Vertovec and Cohen 1999; Bommes 2005). Focus on migration research at the national level also entailed a critique of an undue leveling out of differences within the 'immigration society' by its focus on national-level outcomes rather than more refined, and complex, outcomes at a more local level. Moreover, the development of the segmented assimilation theory of Portes and Zhou (1993), which focused on the importance of contexts of reception in shaping integration outcomes among the second generation, and the rise in popularity of transnationalism approaches (Levitt and Schiller 2004; Levitt

\footnotetext{
${ }^{9}$ It is important to note here that in her article, Green discusses convergent models with regard to the city as the chosen place, which aligns quite well with Glick-Schiller and Cagar's (2009) argument that the city should be the main focal point for studies of integration.
} 
and Jaworsky 2007), which emphasize the trans-border feature of migration for migrants and their children, also stimulated such a shift. The approaches' focus contributed to raise contextual features at the local and national levels to powerful explanans in the analysis of integration trajectories (OECD 2006; Crul et al. 2012; Crul and Mollenkopf 2012).

On the other hand, an array of various "political" factors also account for the prominence of divergent study designs. Firstly, the post-colonial era and the relative 'liberalization' of migration has prompted the development of new, more dispersed migration patterns beyond that of binding a specific origin country to a specific immigration one (Simon 2008), thus allowing for the study of groups with similar migration backgrounds in multiple locales. Moreover, an effort in trying to harmonize or compare migration policies at the European level using tools such as MIPEX (Huddleston et al. 2011) has allowed a certain degree of analytical oversight over the effectiveness of policies and the main contextual drivers of differences in integration outcomes (OECD 2010). Last, but not least, the increase in large-scale, harmonized cross-national studies such as the PISA studies and the accompanying pressures of comparing the effectiveness of various national institutions, such as school systems, has also facilitated divergent models of comparison (OECD 2006). These are just a few of the factors that promoted a conceptual shift away from migration and integration as a pure national issue toward a systematic analysis of contextual features influencing the integration process of children of immigrants. This, to a certain extent, can also be witnessed in the surveys examined in this chapter.

Above and beyond issues related to the trade-offs between convergent and divergent models is the issue of identifying the place where the comparisons occur. ${ }^{10}$ In the non-specific surveys and in some specific surveys (such as SCIICS), the country is used as the geographical level of analysis and the sampling is performed in a way to provide representative samples of the national populations (as much as possible). As useful as these surveys might be with drawing a 'national-level' picture of the outcomes of the children of immigrants and allowing for comparisons between countries, they are also falling into the trap of methodological nationalism, as explained above. In order to avoid such a trap, it is argued that analyses of migrants' outcomes are more suited to a lower geographical level (i.e. cities) as much movement and settlement happens at that level. This helps a more complete understanding of migrants' and their descendants' trajectories especially when taking a comparative perspective (Snyder 2001; Cross and Moore 2002; Glick Schiller and Çağlar 2009).

\footnotetext{
${ }^{10}$ Another element that is of relevance here is the issue of place with regard to the sending country and see whether the locality of origin (whether rural or urban) of the immigrant parents (or immigrant children) is an important driving factor influencing integration outcomes. Whilst we do not focus on this aspect in this section, we highlight its importance and the fact that some of the surveys, such as TIES, include elements about the parents' place of origin in their questionnaires, which can deal with this issue.
} 
This importance of cities in shaping everyday lives of their residents has been picked up by many recent European studies that have shifted the unit of analysis from the nation-state to the city. Examples of such studies, some of which use the data outlined above, include Bolzman et al.'s study of children of Italian and Spanish immigrants in Geneva and Basel (2003); Fibbi et al.'s analysis of discrimination against the children of immigrants in the Zurich and Geneva areas (2003); Aybek's analysis of vocational training for children of immigrants in Munich and Frankfurt (2010); Schnell et al.'s study of neighborhood integration in six European cities (2012); and the importance of language in integration of ethnic minorities in Brussels (Veny and Jacobs 2014). A good proportion of the data surveyed in this chapter also uses the city, and more specifically its neighborhoods and schools, as the main geographical level of analysis. This allows researchers to examine processes and outcomes for the children of immigrants and to grasp and understand these complex dynamics at a very small scale, such as the ones presented by Santelli in Chap. 7.

Yet how far one needs or wants to disaggregate in order to capture complexity and nuance in survey data is problematic and contingent on many issues, such as representativeness; desire for detail; ease of access; and generalizability. This focus on cities has indeed contributed to deconstruct the notion of 'the destination country' beyond the national frame, situating the experiences of the children of immigrants within the local context in which they conduct their everyday lives. It is, however, the case that these cities are still embedded within countries and specific national-level policies for immigration and integration cannot be totally ignored. This reality, and the way in which the local and institutional or national dimensions interact and can help understand integration outcomes, is something that Crul and Schneider (2010) explore in their comparative integration context theory.

It remains the case that, when using city-based data, most of the conclusions can rarely go beyond the city level and be generalizable to the national level, an issue that we will discuss in the last Sect. 2.6 of this chapter. Whilst city-focused surveys allow to explore the dynamics of integration for a large proportion of the children of immigrants as a whole, given the general urban nature of migratory flows (Simon 2008), they do ignore the experiences of individuals and their parents who have settled in non-, or less, urban areas. This is where surveys conducted at the national level can allow researchers to explore the long-term experiences of the groups with non-typical migratory patterns, if such individuals are present in large enough numbers.

\subsection{Benchmarking the Comparisons}

One of the intrinsic purposes of research on the children of immigrants is comparison and one might argue that, on the whole, every research endeavor in migration research is, at its core, comparative (Green 1994; Bloemraad 2013). Comparisons indeed allow researchers to assess the children of immigrants' positioning and level of integration in their parents' host society, even if not always explicitly stated. Yet, in contrast with what Bloemraad (2013: 41) argues, the comparative benchmark is 
not always the non-immigrant population. In fact, we can think of many groups to which researchers can compare the children of immigrants with that steers away from the usual majority/minority comparison dichotomy. In this section we will highlight possible comparisons, including the one mentioned above, in the European data, as well as the implications that such comparisons might have. All these types of comparisons, which can lead to different conclusions, are not necessarily mutually exclusive; they can be combined as well. They are, however, driven by the researchers' theoretical framework and limited by the type of data used for analyses.

\subsubsection{The Majority/Minority Dichotomy}

It is the case that many of the surveys that we have highlighted in this chapter allow for comparing the children of immigrants with the non-immigrant population. Analytically speaking, using the majority/minority dichotomy can be useful. It allows for researchers to measure the 'distance' in outcomes between the groups. This is often understood as being a good proxy for measuring the level of integration of the children of immigrants, by examining whether the differentials with the 'native' population are positive, negative, or even do exist. Whether this is an accurate measure of the level of integration is something that has been debated in academic circles (Alba and Holdaway 2013).

How this non-immigrant population is defined is in itself problematic. In most research using such a benchmark, the term 'native' is used. Such established denomination derives from countries following the jus-soli principle, where place of birth grants citizenship rights. It can be argued that using such terminology fosters a language of exclusion, given the fact that the second (and even later) generation can also be considered native given the locality of their birth. In some instances, however, it accurately portrays a situation where even children born in the receiving countries do not hold similar rights as their peers born of non-immigrant parents, such as citizenship, which can have an important impact on their integration outcomes (e.g. Switzerland, see Fibbi and Wanner 2004). Furthermore, some could argue that such a simple dichotomy ignores the important heterogeneity within the 'native' group with regard to social and/or ethnic background, making this group a very unspecific benchmark for comparison. The alternative majority/minority dichotomy is not yet well established in sociological research, but is occurring more frequently in cross-cultural psychology research.

In the data surveyed for this chapter, all included a potential comparison with the 'native' population. For instance, in the CILS4EU data 'natives' are defined as respondents who were born in the survey country and whose parents and grandparents were also born in the survey country (Dollmann et al. 2014: 13). The EFFNATIS study limits the selection criterion for natives to respondents' and parents' country of birth (EFFNATIS 2001: 40). Yet, just as the choice of which target group to portray poses problems, so does the selection of the 'native' comparison group. Questions arise as to which 'native' individuals are appropriate, be it with regard to 
their age, socio-economic status, or geographical location. The TIES data, for example, selected 'native' peers from the same neighborhoods from which they sampled the children of immigrants (Groenewold and Lessard-Phillips 2012), allowing for a comparison group with similar age ranges and socio-economic circumstances (if not background). The CILS4EU data also sampled native peers within the schools (CILS4EU 2012a, b), which effectively allows for similar comparisons in outcomes.

\subsubsection{Intergenerational Comparisons}

Another way in which to compare the children of immigrants is via intergenerational comparisons. Given the various meanings of 'generation' in sociological research, this implies that the children of immigrants can be compared in different intergenerational ways. First of all, the children of immigrants can be compared across immigrant generations, usually with the first generation, sometimes with 'higher up' generations, if such exist or are identifiable in the data. This allows researchers to measure levels of integration with less or more established groups that have some migration history in common. In such instances, however, issues of measurement, cohort, and context require special attention. Secondly, the children of immigrants can be compared inter-generationally in a more demographic sense of the term, in that the outcomes of the children of immigrants can be compared to that of their parents (above and beyond using parental characteristics as controls in a regression model). This makes it possible to assess the extent to which the children of immigrants fare in the parents' host countries and are able to reproduce or avoid the (dis)advantages experienced by their parents. Special attention to the variations in context and cohorts, as well as similar trends for individuals without an immigrant parentage ought to be taken into account when trying to assess integration outcomes in this manner.

Quite a few of the surveys we have highlighted in Table 2.3 allow for both types of comparisons. Immigrant intergenerational comparisons are possible in the surveys that have a more inclusive target group, in that it is possible to separate the second from other generations. SCIICS, for example, enables comparisons with more established groups in the host societies. As interesting as these comparisons are, the fact that some of the groups' numbers are small or that not a significant proportion of individuals exist of the 'appropriate' generation restricts researchers in performing meaningful analyses or comparing across national or ethnic groups.

In order to compare the children of immigrants with their parents, information about parental characteristics is necessary. One important barrier to conducting such intergenerational comparisons comes from the matter of accurate measurement of parental socio-economic status and more specifically of the pre-migration status and the possible downward mobility in post-migration occupations. These measurement issues make it difficult to truthfully compare outcomes between children and parents. Moreover, there is a heightened risk to practice some undue sociocentric nominalism that takes the educational and occupational hierarchy of the 
country of residence as the benchmark for the evaluation of the parents' human, social, and cultural capital in the country of origin. One possible consequence is a flattening of the relative importance of parental influence in such matters.

In the surveys examined, only the CILS4EU and TIES data include information about parents that can realistically allow for this type of intergenerational comparison. ${ }^{11}$ Given the young age of the CILS4EU respondents, where information was collected directly from the parents (in wave 1 only), direct intergenerational comparison of outcomes are difficult, if not impossible. In the TIES data, on the other hand, the (young) adult respondents were asked to provide parental information themselves, hence allowing for intergenerational comparisons that are marred by issues of misreporting, as is often the case when respondents are asked to provide information about their parents (Lessard-Phillips and Ross 2012). Hence, lack of accurate and timely information and issues of measurement make it quite difficult to analyze the outcomes of both immigrants and their children simultaneously. A partial solution to this might be to follow that of Rothon et al. (2009) and others and use the non-specific surveys to create synthetic parental cohorts in previous survey years as a benchmark for comparison.

\subsubsection{Comparisons Between and Within Groups}

Comparisons involving different groups of children of immigrants are another way in which to compare outcomes, if only to identify possible distinctive patterns of community 'success' and the types of factors that might help explain the variation in outcomes between and within ethnic or national groups. This can be done either by comparing similar origin groups in different cohorts, at a similar point in time or at different points in time, or by comparing within cohorts, with an emphasis on the comparison between groups of different ethnic or national origins. The latter type of comparisons can be done directly, by not using the 'native' group as a comparison, either for theoretical reasons or because of data constraints. It can also be done indirectly, by making the minority/majority comparison but only focusing on the difference in coefficients with the reference category, in this case the 'native' group, but not between the children of immigrants groups, comparatively examining the relative distances between the majority and the minority groups (see, for example, Lessard-Phillips et al. 2012; Huschek et al. 2011 or Baysu and de Valk 2012). The former type of comparison involves the operationalization of specific cohorts of children of immigrants (either with regard to age or periods, for example) and the comparisons of outcomes across those cohorts. Ideally within group comparisons allow to measure the level of progress certain ethnic or national groups have made with regard to integration against the benchmark of another group's performance, however defined, keeping the comparisons between immigrant generations.

\footnotetext{
${ }^{11}$ In the non-specific surveys, some parental information is available (such as in PISA), but these also encounter similar issues as those mentioned above.
} 
Within-group comparisons within a specific cohort allow for an examination of the way in which different ethnic or national groups negotiate in similar societal structures and institutional constraints that might not be relevant for the non-immigrant populations.

In the data that we surveyed, within-group comparisons of the latter type are possible. The TIES survey, for example, allows comparing the outcomes of secondgeneration individuals from specific origins within the selected cities (and, to some extent, between). This has been done in a comparative as well as a national manner (see Crul and Heering 2008; Crul et al. 2012; Fibbi et al. 2014 and Groenewold et al. 2013). By including more than one national or ethnic group as their target groups, all the surveys outlined in the Table 2.3 have the potential for within group comparisons. The design of second-generation specific surveys, however, does not allow for comparison across cohorts, given the focus on the target group and the limited age ranges. This is where the non-specific surveys allow, sample size permitting, an examination of various groups in different age cohorts, to account for contextual and institutional variations that might have affected their life outcomes, on top of other factors.

This section showed that it is possible to think beyond the majority/minority dichotomy when comparing the children of immigrants against a benchmark to assess their level of integration. Evidently this implies that the types of conclusions that we can reach are dependent on the comparisons drawn. On the one hand, comparison with the 'non-immigrant mainstream' allows for examining the distance between the majority and minority groups in terms of specific outcomes. On the other hand, more nuanced comparisons involving inter- and intra-generational patterns allow to see integration processes in a different light, potentially testing group differences among ethnic and national groups in similar contexts and allowing to investigate the differentiated impact that various individual, family, and community factors as well as institutional and structural barriers might have. Most of these comparative choices are, of course, theoretically grounded, but we have also shown that data constraints limit the types of comparisons on offer for quantitative researchers (notwithstanding more technical issues, which we are not discussing here). In our opinion, the outcomes under study (whether or not they are directly related to integration issues) are multifaceted, in a very broad understanding of the term; in order to better understand the position of the children of immigrants in the European countries they grow up in, a flexible and multifaceted approach to analyzing and comparing their outcomes is warranted.

\subsection{Choices and Their Implications for Research}

The choices that are being made with regard to the definition of the target group, the geographical level of comparison, and the benchmark against which to compare the outcomes of the children of immigrants inevitably lead to biases that can taint our overarching conclusions. Such biases are often mentioned in research, mostly in 
passing, but they and the impact that they might have on analyses, are not necessarily always explored in great depth. We attempt to explore some of these in this section.

When defining the children of immigrants as an object of enquiry via survey tools, important theoretical, institutional, and technical (and even dogmatic) considerations come into play. These relate to the way in which the children of immigrants ought to be defined, either as part of a specific theoretical approach or given institutional constraints and whether appropriate sample sizes are possible to conduct appropriate analyses using a particular definition. Theoretical frames are important, if most important, in driving the analytical choices researchers make, but can be hampered by other types of barriers. As previously mentioned, national constraints with regard to the identification of the children of immigrants (especially those based on citizenship as means of identification, such as in Switzerland, or only using ethnic origin as a differentiating factor) does not allow the accurate identification of individuals of migrant origins. In fact, such identification strategy lumps together the children of immigrants with individuals with little or no immigrant parentage, lending intergenerational comparisons near to impossible. Imaginative and promising tools and methods are being used to circumvent these constraints, such as onomastic sampling, which allows researchers to sample individuals according to the probable national origin of their surnames (Humpert and Schneiderheinze 2000; Schnell et al. 2013) $)^{12}$, or iterative snowball sampling, where an initial random sample of individuals is selected and snowball samples derived from this initial sample (see Laganà et al. 2013; Illenberger and Flötteröd 2012; Kowald et al. 2008). Yet it is the case that barriers do exist and researchers might be unable to study such populations. Some might argue, however, that these barriers represent a more inclusive approach to studying individuals with a shared national origin and that emphasizing differences based on parentage leads to more division than unity.

As we have discussed, the choice of the level of comparison can also lead to bias, especially if the conclusions reached are done at the "incorrect" level of analysis. A focus at the country level is guilty of methodological nationalism, whilst it gives great insights into the general situation and potential influence of national contexts, it ignores important nuances in outcomes and processes that ought to be happening at the sub-national level. On the other hand, sub-national levels of analysis, which offer a more realistic and nuanced picture of the situation that fits more sensibly to the immigrant experience, either ignore the greater institutional context in which they are based or over-generalize the power of the national context based on analyses at the sub-national level. In both instances researchers risk encountering some type of ecological (in the former case) and exception (in the latter case) fallacy issues. Given that the choice of level is one that is intrinsic to surveys of the children of immigrants, such biases are inevitable and influence research questions and conclusions. They are important to acknowledge and should not be ignored, or at least warrant a degree of caution in formulating conclusions.

\footnotetext{
${ }^{12}$ As Groenewold and Lessard-Phillips (2012) have highlighted, using onomastic samples to identify the second generation is not without its share of issues.
} 
There are also numerous possible biases arising from the type of benchmark used in the comparison, which have important consequences for the types of conclusions one might draw about the level of progress, or 'success', of the children of immigrants. ${ }^{13}$ For example, whereas comparing the children of immigrants to the 'native' population might lead researchers to conclude that the level of progress is not 'on par', a more intergenerational approach that focuses on a comparison with the immigrant parents or first-generation peers might provide a different, if not opposite, picture of the situation. This is heavily dependent on how one defines, perceives, and measures integration, both theoretically and methodologically.

Bias, however, is not solely restricted to these choices; it also arises via the sampling of the population of interest and its levels of selectivity. With regard to the immigrant population, selectivity can take two forms. On the one hand, it might be the case that immigrants are (self-) selected from the higher or lower end of the skills distribution (such as education) and thus exhibit socio-economic characteristics that might heavily influence their and their children's outcomes. On the other hand, it might also be the case that the sampled individuals in a given survey are not representative of the population they have been sampled to represent (at any level) and tend to be biased toward the higher end of the socio-economic spectrum. This holds for both migrant and non-migrant respondents but is especially problematic for individuals with immigrant parentage, who are considered hard-to-reach populations (Atkinson and Flint 2001; Teitler et al. 2003).

Another important source of bias is time, more specifically related to the issues of age, period, duration, and cohort effects. As we have seen in the previous Sect. 2.4, comparative benchmarks sometimes involve individuals from different ages, cohorts, and generations. These individuals might have had different experiences with regard to their migration histories (especially if they are migrants themselves) and the contexts in which they have evolved that are difficult to reconcile in regression analysis by simply controlling for age. One solution for such issue is to control for both age and period, if the data at hand allows for such comparisons (Huschek et al. 2011). Moreover, an important factor such as time since migration, quite important to understand migrant outcomes, becomes obsolete (or difficult to disentangle) when analyzing the outcomes of the children of immigrants alongside that of first-generation immigrants, as children born in the receiving country are not directly prone to such influence. Solutions to these temporal biases have been put forward in the immigration literature, with more recent efforts borrowing analytical tools from fertility research to measure first-generation immigrant advancement (Pitkin and Myers 2011) but with little to no applicability to the children of immigrants, according to the authors. Trying to find an analytically workable solution is still being debated.

\footnotetext{
${ }^{13}$ The types of indicators of 'success' (e.g. educational, occupational, financial) are also a potential source of bias.
} 


\subsection{Conclusions}

Our aim in this chapter was to highlight the potential challenges that arise when assessing the life outcomes of the children of immigrants (and beyond) using surveys. These are not only theoretical but also methodological in nature and include issues of definition, choice of level of analysis, types of comparisons, and the various biases linked to these and other sources. These challenges, which are nearly inevitable and ought to be taken seriously as they have important ramifications for the analyses and conclusions one might reach, were exemplified by a review of the recent existing European surveys with children of immigrants as their target populations. Each and every one of these surveys is an important tool to better understand the life chances of immigrant generations but in a slightly different manner, as their design encompass different choices made with regard to the challenges mentioned above.

As much as these endeavors have a positive effect on our understanding of longterm immigrant integration patterns and processes in Europe, it still remains the case that more survey efforts are needed in order to lend more complexity and nuance to this picture. One type of comparison that should be mentioned but has not been considered in this chapter is that of comparing the outcomes of the children of immigrants with cohorts in the origin countries. This helps see whether the outcomes of the children of immigrants can be related in part to their immigration background or simply follows the trends of individuals in their cohorts in their parents' countries of origin. This type of comparison is possible with other available data, either on their own or used in conjunction with existing surveys, such as the Migration between African and Europe (MAFE) study (Beauchemin and GonzalezFerrer 2010) or the Push and Pull Factors in International Migration project (Schoorl et al. 2000), which allow for origin and destination comparisons of individual outcomes (but with the main focus being on the first generation). New initiatives to develop comparisons with second generation young adults in Europe with young adults in different countries of origin are developed for example in the FaMiLife (Families of migrant origin: A life course perspective project, see the FaMiLife website).

We also believe, much in line with transnational approaches, that a renewed focus on the family and social networks is warranted and should be adequately measured in survey data. Given the financial and methodological difficulties in collecting and analyzing such data, researchers might need to resort to more traditional yet refined survey tools to include such important actors. The future of survey research on the children of immigrants, in our view, rests on the maintenance and development of retrospective and longitudinal research. This aspect is present to a certain extent in the CILS4EU data and partially captured in the TIES data in which friendship networks at different moments in youth are questioned. However, further and more detailed data collection is needed on this point for a more long-term overview of the integration process. It also rests on the development of existing and new methodologies allowing for more detailed analyses of existing data, or at least the 
focus on analytical tools going beyond regression analysis, such as matching techniques, structural equation modeling, the use of simulation, and a foray into mixed methods.

Yet, short of using very complex methods of analysis, it might also be the case that the limitations of quantitative methodologies do allow to only partially grasp such complexity and nuance. In addition to using more advanced analytical tools and improve data collection and their use, another way forward is to focus more on the processes rather than the outcomes, in order to tackle and understand the mechanisms at play in the lives of children of immigrants across Europe.

Acknowledgements This paper benefited from the support of the Swiss National Centre of Competence in Research LIVES-Overcoming Vulnerability: Life Course Perspectives, which is financed by the Swiss National Science Foundation (Grant number: 51NF40-160590). Laurence Lessard-Phillips gratefully acknowledges the support of the Economic and Social Research Council (grant number ES/K009206/1-2) for conducting this work.

\section{References}

Adams, R., \& Wu, M. (2002). PISA 2000 technical report. Organisation for Economic Co-operation and Development (OECD). http://www.oecd.org/pisa/pisaproducts/33688233.pdf. Accessed 6 Dec 2013.

Alba, R., \& Holdaway, J. (2013). The Children of immigrants at school: A comparative look at integration in the United States and Western Europe. New York: New York University Press: Social Science Research Council.

Atkinson, R., \& Flint, J. (2001). Accessing hidden and hard-to-reach populations: Snowball research strategies. Social Research Update - Issue 33. http://sru.soc.surrey.ac.uk/SRU33.pdf. Accessed 11 Aug 2015.

Aybek, C. M. (2010). Young immigrants' low participation in the German vocational training system: how local actors in Munich and Frankfurt/Main try to make a difference. In T. Caponio \& M. Borkert (Eds.), The local dimension of migration policymaking (pp. 85-108). Amsterdam: Amsterdam University Press.

Baysu, G., \& de Valk, H. (2012). Navigating the school system in Sweden, Belgium, Austria and Germany: School segregation and second generation school trajectories. Ethnicities, 12, 776-799.

Beauchemin, C., \& Gonzalez-Ferrer, A. (2010). Multi-country surveys on international migration: An assessment of selection biases in destination countries, MAFE working paper. Paris: INED.

Bloemraad, I. (2013). The promise and pitfalls of comparative research design in the study of migration. Migration Studies, 1, 27-46.

Bolzman, C., Fibbi, R., \& Vial, M. (2003). Secondos-Secondas: Le processus d'intégration des jeunes adultes issus de la migration espagnole et italienne en Suisse. Zurich: Editions Seismo.

Bommes, M. (2005). Transnationalism or assimilation? JSSE-Journal of Social Science Education, 4, 14-30.

Bovenkerk, F., Miles, R., \& Verbunt, G. (1991). Comparative studies of migration and exclusion on the grounds of "race" and ethnic background in Western Europe: A critical appraisal. International Migration Review, 25, 375-391. doi:10.2307/2546293.

Breen, R., \& Jonsson, J. O. (2005). Inequality of opportunity in comparative perspective: Recent research on educational attainment and social mobility. Annual Review of Sociology, 31, 223 243. doi:10.1146/annurev.soc.31.041304.122232. 
Carol, S., Ersanilli, E., \& Wagner, M. (2014). Spousal choice among the children of Turkish and Moroccan immigrants in six European countries: Transnational spouse or co-ethnic migrant? International Migration Review, 48, 387-414. doi: 10.1111/imre.12068.

CILS4EU Children of Immigrants Longitudinal Survey in Four European Countries. (2012a). Official website. http://www.cils4.eu/. Accessed 29 Oct 2013.

CILS4EU Children of Immigrants Longitudinal Survey in Four European Countries. (2012b). Technical report, Wave 1 - 2010/2011, v1.0.0. Mannheim University. http://www.cils4.eu/ images/CILS4EU_Technical\%20Report.pdf. Accessed 29 Oct 2013.

Collett, E. (2013). Facing 2020: Developing a new European agenda for immigration and asylum policy. Migration Policy Institute Europe. http://www.migrationpolicy.org/research/facing2020-developing-new-european-agenda-immigration-and-asylum-policy. Accessed 11 Aug 2015.

Cross, M., \& Moore, R. S. (Eds.). (2002). Globalization and the new city: migrants, minorities and urban transformations in comparative perspective. New York: Palgrave.

Crul, M., \& Heering, L. (Eds.). (2008). The position of the Turkish and Moroccan second generation in Amsterdam and Rotterdam. The TIES Study in the Netherlands. Amsterdam: Amsterdam University Press.

Crul, M., \& Mollenkopf, J. H. (Eds.). (2012). The changing face of world cities: the second generation in Western Europe and the United States. New York: Russell Sage Foundation.

Crul, M., \& Schneider, J. (2010). Comparative integration context theory: participation and belonging in new diverse European cities. Ethnic and Racial Studies, 33, 1249-1268. doi:10.1080/01419871003624068.

Crul, M., \& Vermeulen, H. (2003). The second generation in Europe. International Migration Review, 37, 965-986. doi:10.1111/j.1747-7379.2003.tb00166.x.

Crul, M., Schneider, J., \& Lelie, F. (2012). The European second generation compared: Does the integration context matter? Amsterdam: Amsterdam University Press.

De Valk, H. A. (2010). Children of immigrants in the Netherlands: Growing up in diversity. Child Indicators Research, 3(4), 503-524.

de Valk, H. A. G., Koelet, S., \& van der Erf, R. (2015). Intra-Europese migratie: een demografische achtergrond bij migratiepatronen en inter-Europese partnerschappen in vergelijkend perspectief. In C. Timmerman, R. Mahieu, F. Levrau, \& D. Vanheule (Eds.), Intra-Europese migratie en mobiliteit; andere tijden, nieuwe wegen? (pp. 31-51). Leuven: Universitaire Pers Leuven.

Dollmann, J., Jacob, K., \& Kalter, F. (2014). Working paper - Examining the diversity of youth in Europe. A Classification of Generations and Ethnic Origins Using CILS4EU Data. Technical Report. Mannheimer Zentrum für Europäische Sozialforschung. http://www.mzes.unimannheim.de/publications/wp/wp-156.pdf. Accessed 12 May 2014.

Dronkers, J., \& De Heus, M. (2013). Immigrant children's academic performance: The influence of origin, destination, and community. In D. Meyer \& A. Beano (Eds.), PISA, power and policy: The emergence of global educational governance (pp. 247-265). Oxford: Symposium Books.

EDUMIGROM Ethnic differences in education and diverging prospects for urban youth in an enlarged Europe. (2008). Official website. http://www.edumigrom.eu. Accessed 29 Oct 2013.

EFFNATIS Effectiveness of National Integration Strategies Towards Second Generation Migrant Youth in a Comparative European Perspective. (2001). Final report. European Forum for Migration Studies (efms). http://www.efms.uni-bamberg.de/pdf/finalreportk.pdf. Accessed 29 Oct 2013.

Ersanilli, E., \& Koopmans, R. (2009). Ethnic retention and host culture adoption among Turkish immigrants in Germany, France and the Netherlands: A controlled comparison, Discussion paper SP IV 2009-701. Berlin: WZB Wissenschaftszentrum Berlin für Sozialforschung.

Ersanilli, E., \& Koopmans, R. (2013). The Six Country Immigrant Integration Comparative Survey (SCIICS): Technical report, Discussion paper SP VI 2013-102. Berlin: WZB Wissenschaftszentrum Berlin für Sozialforschung.

ESS European Social Survey. (2013). Official website. http://www.europeansocialsurvey.org. Accessed 29 Oct 2013. 
European Commission. (2011). Migrants in Europe: A statistical portrait of the first and second generation. Luxembourg: Publications Office of the European Union.

EUROSTAT. (2013). European Union Statistics on Income and Living Conditions (EU-SILC). In European Commission - EUROSTAT. http://epp.eurostat.ec.europa.eu/portal/page/portal/ microdata/eu_silc

EUROSTAT website EU labour force survey - ad hoc modules - Statistics Explained. http://epp. eurostat.ec.europa.eu/statistics_explained/index.php/EU_labour_force_survey_-_ad_hoc_ modules. Accessed 23 May 2014.

EVS European Value Survey - GESIS Leibniz-Institut für Sozialwissenschaften. (2013). Official website. http://www.gesis.org/en/services/data-analysis/survey-data/european-values-study/. Accessed 29 Oct 2013.

FaMiLife Project: Families of Migrant Origin: A life course perspective. (2014). NIDI Netherland Interdisciplinary Demographic Institute http://www.nidi.knaw.nl/en/research/mm/230019. Accessed 23 May 2014.

Fibbi, R., \& Wanner, P. (2004). La migration entre démographie et démocratie. In C. Suter \& D. Joye (Eds.), Rapport social 2004 (pp. 100-124). Zurich: Seismo.

Fibbi, R., Kaya, B., \& Piguet, E. (2003). Le passeport ou le diplôme? Étude des discriminations à l'embauche des jeunes issus de la migration: Rapport de recherche établi à l'intention du FNS dans le cadre du PNR 43.

Fibbi, R., Lerch, M., \& Wanner, P. (2005). Processus de naturalisation et caractéristiques socioéconomiques des jeunes issus de la migration. In R. Fibbi, M. Lerch, P. Wanner, et al. (Eds.), L'intégration des populations issues de l'immigration en Suisse: personnes naturalisés et deuxième génération (pp. 9-60). Neuchâtel: Office fédéral de statistique.

Fibbi, R., Topgül, C., Ugrina, D., \& Wanner, P. (2014). The new second generation: Youth of Turkish and former Yugoslav descent in Zurich and Basel. Amsterdam: Amsterdam University Press.

Fleischmann, F., \& Phalet, K. (2012). Integration and religiosity among the Turkish second generation in Europe: A comparative analysis across four capital cities. Ethnic and Racial Studies, 35(2), 320-341.

Fonseca, M. L., McGarrigle, J., \& Esteves, A. (2013). Neighborhood integration in European multi-ethnic cities: Evidence from the Geitonies project. Finisterra, 48(96), 7-16.

Foy, P., Arora, A., \& Stanco, G.M. (2011). TIMSS 2011 User Guide for the International Database. TIMSS Trends in International Mathematics and Science Study. http://timss.bc.edu/timss2011/ downloads/T11_UserGuide.pdf. Accessed 6 Dec 2013.

GEITONIES Generating Interethnic Tolerance and Neighbourhood Integration in European Urban Space. (2008). Official website. http://geitonies.igot.ulisboa.pt/. Accessed 29 Oct 2013.

Gesis. (2014). GESIS - Eurobarometer: national_provenance. Available from http://www.gesis. org/eurobarometer-data-service/topics-trends-question-retrieval/eb-trends-trend-files/list-oftrends/national-provenance/. Accessed 23 Oct 2015.

GGP Generation \& Gender Programme. (2013). Official website. http://www.ggp-i.org/. Accessed 29 Oct 2013.

Glick Schiller, N., \& Çağlar, A. (2009). Towards a comparative theory of locality in migration studies: Migrant incorporation and city scale. Journal of Ethnic and Migration Studies, 35, 177-202. doi:10.1080/13691830802586179.

Górny, A., \& Toruńczyk-Ruiz, S. (2013). Neighbourhood attachment in ethnically diverse areas: The role of interethnic ties. Urban Studies, 51, 1000-1018. doi:10.1177/0042098013494418.

Green, N. L. (1994). The comparative method and poststructural structuralism: new perspectives for migration studies. Journal of American Ethnic History, 13, 3-22. doi:10.2307/27501896.

Groenewold, L.-P., \& Lessard-Phillips, L. (2012). Research methodology. In M. Crul, J. Schneider, \& F. Lelie (Eds.), The European second generation compared: Does the integration context matter? (pp. 39-56). Amsterdam: IMISCOE Research - Amsterdam University Press.

Groenewold, G., de Valk, H. A., \& Van Ginneken, J. (2013). Acculturation preferences of the Turkish second generation in 11 European cities. Urban Studies. doi:10.1177/0042098013505890. 
Guiraudon, V. (2003). The constitution of a European immigration policy domain: a political sociology approach. Journal of European Public Policy, 10(2), 263-282.

Guiraudon, V., \& Lahav, G. (2000). A Reappraisal of the state sovereignty debate the case of migration control. Comparative Political Studies, 33(2), 163-195.

Heath, A. F., \& Brinbaum, Y. (2014). Unequal attainments: Ethnic educational inequalities in ten Western countries, Proceedings of the British Academy 196. Oxford: Oxford University Press for the British Academy.

Heath, A. F., \& Cheung, S. Y. (2007). Unequal chances: ethnic minorities in Western labour markets. Oxford: Oxford University Press for the British Academy.

Heath, A. F., Rothon, C., \& Kilpi, E. (2008). The second generation in Western Europe: Education, unemployment, and occupational attainment. Annual Review of Sociology, 34, 211-235.

Hernandez, D. J., Macartney, S., \& Blanchard, V. L. (2009). Children in immigrant families in eight affluent countries: Their family, national and international context. Florence: Innocenti Research Centre, UNICEF.

Huddleston, T., Niessen, J., Chaoimh, E. N., \& White, E. (2011). MIPEX migrant integration policy index 2011. Brussels: The British Council and Migration Policy Group.

Humpert, A., \& Schneiderheinze, K. (2000). Stichprobenziehung für telefonische Zuwandererumfragen: Einsatzmöglichkeiten der Namenforschung. ZUMA-Nachrichten, 24/47, 36-63.

Huschek, D., Liefbroer, A. C., \& de Valk, H. A. (2010). Timing of first union among secondgeneration Turks in Europe: The role of parents, peers and institutional context. Demographic Research, 22(16), 473-504.

Huschek, D., de Valk, H. A. G., \& Liefbroer, A. C. (2011). Does social embeddedness influence union formation differences among the Turkish and Moroccan generation in the Netherlands? Journal of Comparative Family Studies, 42(6), 787-808.

Illenberger, J., \& Flötteröd, G. (2012). Estimating network properties from snowball sampled data. Social Networks, 34(4), 701-711.

Jacob, K., \& Kalter, F. (2013). Intergenerational change in religious salience among immigrant families in four European countries. International Migration, 51, 38-56. doi:10.1111/ imig. 12108.

Kampakoglou, M., Kleideri, M., \& Ieromnimon, T. (2012). Working paper with the description of the income and living conditions dataset. Eurostat. http://epp.eurostat.ec.europa.eu/portal/ page/portal/income_social_inclusion_living_conditions/documents/tab/Tab/Working_paper_ on_EU_SILC_datasets.pdf. Accessed 22 May 2014.

Kowald, M., Frei, A., \& Hackney, J. K. (2008). Spatial relationships and social networks: An iterative survey approach. Zürich: ETHZ Eidgenössische Technische Hochschule Zürich, Institut für Verkehrsplanung und Transportsysteme.

Labrianidis, L., Hatziprokopiou, P., Pratsinakis, M., \& Vogiatzis, N. (2010). GEITONIES - City survey report: Thessaloniki. http://geitonies.igot.ulisboa.pt/Publication/THESSALONIKI\%20 City\%20Survey\%20Report.pdf. Accessed 29 Oct 2013.

Laganà, F., Elcheroth, G., Penic, S., Kleiner, B., \& Fasel, N. (2013). National minorities and their representation in social surveys: Which practices make a difference? Quality \& Quantity, 47(3), 1287-1314.

Lanzieri, G. (2011). Fewer, older and multicultural? Projections of the EU populations by foreign/ national background. Luxembourg: Publications Office of the European Union.

Lessard-Phillips, L., \& Ross, C. (2012). The TIES respondents and their parents: Background socio-demographic characteristics. In M. Crul, J. Schneider, \& F. Lelie (Eds.), The European second generation compared (pp. 57-100). Amsterdam: Amsterdam University Press.

Lessard-Phillips, L., Fibbi, R., \& Wanner, P. (2012). Assessing the labour market position and its determinants for the second generation. In M. Crul, J. Schneider, \& F. Lelie (Eds.), The European second generation compared (pp. 165-224). Amsterdam: Amsterdam University Press. 
Lessard-Phillips, L., Fleischmann, F., \& van Elsas, E. (2014). Ethnic minorities in ten Western countries: Migration flows, policies and institutional differences. In A. F. Heath \& Y. Brinbaum (Eds.), Unequal attainments: Ethnic educational inequalities in ten Western countries (pp. 25-61). Oxford: Oxford University Press for the British Academy.

Levitt, P., \& Jaworsky, B. N. (2007). Transnational migration studies: Past developments and future trends. Annual Review of Sociology, 33, 129-156. doi:10.1146/annurev.soc.33.040406.131816.

Levitt, P., \& Schiller, N. G. (2004). Conceptualizing simultaneity: A transnational social field perspective on society. International Migration Review, 38, 1002-1039. doi:10.1111/j.1747-7379.2004. tb00227.x.

LOCALMULTIDEM Multicultural Democracy and Immigrants Social Capital in Europe: Participation, Organisational Networks, and Public Policies at the Local Level. (2009a). Official website. http://www.um.es/localmultidem. Accessed 29 Oct 2013.

LOCALMULTIDEM Multicultural Democracy and Immigrants' Social Capital in Europe: Participation, Organisational Networks, and Public Policies at the Local Level. (2009b). Executive final activity report. University of Murcia. http://www.um.es/localmultidem/projectoutputs.php?type=R. Accessed 29 Oct 2013.

Lucassen, J., \& Lucassen, L. (2013). European migration history. In S. J. Gold \& S. J. Nawyn (Eds.), The Routledge international handbook of migration studies (pp. 52-63). Abingdon: Routledge.

McAndrew, S., \& Voas, D. (2014). Immigrant generation, religiosity and civic engagement in Britain. Ethnic and Racial Studies, 37(1), 99-119.

Messing, V. (2011). EDUMIGROM: Methodological issues and research tools - presented at the "Ethnic Difference in Education across Europe" Conference (Central European University Budapest, Hungary: 11-12 February 2011). http://www.edumigrom.eu/sites/default/files/ field_attachment/page/node-19527/edumigromclosingconferecemessing11-12feb2011_0.pdf. Accessed 29 Oct 2013.

Morales, L., \& Giugni, M. (2011). Political opportunities, social capital and the political inclusion of immigrants in European cities. In L. Morales \& M. Giugni (Eds.), Social capital, political participation and migration in Europe: Making multicultural democracy work? (pp. 1-18). Basingstoke: Palgrave Macmillan.

OECD Organisation for Economic Co-operation and Development. (2005). PISA 2003. Technical report. http://www.oecd.org/edu/school/programmeforinternationalstudentassessmentpisa/35188570.pdf. Accessed 6 Dec 2013.

OECD Organisation for Economic Co-operation and Development. (2006). Where immigrant students succeed: a comparative review of performance and engagement in PISA 2003. Paris: OECD Publishing.

OECD Organisation for Economic Co-operation and Development. (2009). PISA 2006. Technical report. http://www.oecd.org/pisa/pisaproducts/42025182.pdf. Accessed 6 Dec 2013.

OECD Organisation for Economic Co-operation and Development. (2010). Closing the gap for immigrant students: Policies, practice and performance. Paris: OECD Publishing.

OECD Organisation for Economic Co-operation and Development. (2012a). PISA 2009. Technical report. http://www.oecdbookshop.org/oecd/display.asp?lang=EN\&sf1=identifiers \&st1=9789264040182. Accessed 6 Dec 2013.

OECD Organisation for Economic Co-operation and Development. (2012b). PISA untapped skills realising the potential of immigrant students: Realising the potential of immigrant students. Paris: OECD Publishing.

Parameshwaran, M. (2014). Explaining intergenerational variations in English language acquisition and ethnic language attrition. Ethnic and Racial Studies, 37(1), 27-45.

Penn, R. (2006). EFFNATIS research - Course notes/presentation. http://www.maths.lancs. ac.uk/ penn/notes/Soc\%20244/EFFNATIS.pdf. Accessed 31 Oct 2013.

PIRLS Progress in International Reading Literacy Study. (2013). Official website. https://nces. ed.gov/surveys/pirls/index.asp. Accessed 3 Nov 2013. 
Pitkin, J., \& Myers, D. (2011). A summary period measure of immigrant advancement in the US. Demographic Research, 24(12), 257-292.

Portes, A., \& Zhou, M. (1993). The new second generation: Segmented assimilation and its variants. The Annals of the American Academy of Political and Social Science, 530, 74-96. doi:10 $.1177 / 0002716293530001006$.

Portes, A., Aparicio, R., Haller, W., \& Vickstrom, E. (2010). Moving ahead in Madrid: Aspirations and expectations in the Spanish second generation. International Migration Review, 44(4), 767-801.

Rothon, C., Heath, A., \& Lessard-Phillips, L. (2009). The educational attainments of the "second generation": A comparative study of Britain, Canada, and the United States. The Teachers College Record, 111(6), 1404-1443.

Rumbaut, R. G. (2002). Severed or sustained attachments? Language, identity, and imagined communities in the post-immigrant generation. In P. Levitt \& M. Waters (Eds.), The changing face of home: The transnational lives of the second generation (pp. 43-95). New York: Russell Sage Foundation.

Rumbaut, R. G. (2004). Ages, life stages, and generational cohorts: Decomposing the immigrant first and second generations in the United States. International Migration Review, 38(3), $1160-1205$.

Rumbaut, R. G., Massey, D. S., \& Bean, F. D. (2006). Linguistic life expectancies: Immigrant language retention in Southern California. Population and Development Review, 32, 447-460. doi:10.1111/j.1728-4457.2006.00132.x.

Schleicher, A. (2006). Where immigrant students succeed: A comparative review of performance and engagement in PISA 2003 1. Intercultural Education, 17, 507-516. doi:10.1080/14675980601063900.

Schnell, P., Reeger, U., \& Kohlbacher, J. (2012). Neighbourhood embeddedness in six European cities: Differences between types of neighbourhoods and immigrant background. Polish Sociological Review, 4(180), 523-543.

Schnell, R., Gramlich, T., Bachteler, T., Reiher, J., Trappmann, M., Smid, M., \& Becher, I. (2013). A new name-based sampling method for migrants using n-grams. German Record Linkage Center - Working paper series. http://soz-159.uni-duisburg.de/-download=wp-grlc-2013-04. pdf. Accessed 23 May 2014.

Schoorl, J. J., Heering, L., Esveldt, I., Groenewold, G., van der Erf, R., Bosch, A., et al. (2000). Push and pull factors of international migration: A comparative report. Luxembourg: Office for Official Publications of the European Communities.

Setien, M.L., Bartolome, E., Ibarrola, A, Maiztegui, C., Ruiz Vieytez E, Santibañez, R., Vicente, T. (2010) GEITONIES - City survey report: Bilbao.

Simon, P. (2003). France and the unknown second generation: Preliminary results on social mobility. International Migration Review, 37(4), 1091-1119.

Simon, G. (2008). La planète migratoire dans la mondialisation. Paris: Armand Colin.

Snyder, R. (2001). (2001). Scaling down: The subnational comparative method. Studies in Comparative International Development, 36, 93-110. doi:10.1007/BF02687586.

Szalai, J. (2011a). Ethnic differences in education and diverging prospects for urban youth in an enlarged Europe, EDUMIGROM. Summary findings. Budapest: Central European University, Center for Policy Studies.

Szalai, J. (2011b). Contested issues of social inclusion through education in multiethnic communities across Europe, EDUMIGROM final study. Budapest: Central European University, Center for Policy Studies.

Szalai, J., Messing, V., \& Nemenyi, M. (2010). Ethnic and social differences in education in a comparative perspective, EDUMIGROM comparative papers. Budapest: Central European University, Centre for Policy Studies.

Teitelbaum, M. S. (2001). The role of the state in international migration. The Brown Journal of World Affair, 8(2), 157-167. 
Teitler, J. O., Reichman, N. E., \& Sprachman, S. (2003). Costs and benefits of improving response rates for a hard-to-reach population. The Public Opinion Quarterly, 67(1), 126-138.

Thomson, M., \& Crul, M. (2007). The second generation in Europe and the United States: How is the transatlantic debate relevant for further research on the European second generation? Journal of Ethnic and Migration Studies, 33(7), 1025-1041.

TIES The Integration of the European Second Generation. (2013). Official website. http://www. tiesproject.eu/index9ed2.html?lang=en. Accessed 29 Oct 2013.

TNS Opinion \& Social. (2011). Special Eurobarometer 346 - New Europeans - summary. Brussels. Available from: http://ec.europa.eu/public_opinion/archives/ebs/ebs_346_sum_ en.pdf Accessed 23 Oct 2015.

Veny, Y., \& Jacobs, D. (2014). Immigrant inclusion and linguistic struggle in the Brussels-capital region. In K. R. Good, T. Triadafilopoulos, \& L. Turgeon (Eds.), Segmented cities? How urban contexts shape ethnic and nationalist politics (pp. 182-204). Vancouver: UBS Press.

Vertovec, S., \& Cohen, R. (Eds.). (1999). Migration, diasporas, and transnationalism. Aldershot: Edward Elgar.

Waters, M. C. (2014). Defining difference: The role of immigrant generation and race in American and British immigration studies. Ethnic and Racial Studies, 37(1), 10-26.

Wimmer, A., \& Glick Schiller, N. (2002). Methodological nationalism and beyond: Nation-state building, migration and the social sciences. Global networks, 2(4), 301-334.

Open Access This chapter is licensed under the terms of the Creative Commons Attribution 4.0 International License (http://creativecommons.org/licenses/by/4.0/), which permits use, sharing, adaptation, distribution and reproduction in any medium or format, as long as you give appropriate credit to the original author(s) and the source, provide a link to the Creative Commons license and indicate if changes were made.

The images or other third party material in this chapter are included in the chapter's Creative Commons license, unless indicated otherwise in a credit line to the material. If material is not included in the chapter's Creative Commons license and your intended use is not permitted by statutory regulation or exceeds the permitted use, you will need to obtain permission directly from the copyright holder.

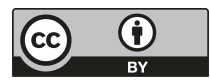

